\title{
Immunoregulatory Effects of Stem Cell-Derived Extracellular Vesicles on Immune Cells
}

\author{
Min Xie ${ }^{1+}$, Wei Xiong ${ }^{2 \dagger}$, Zhou She ${ }^{1}$, Zaichi Wen ${ }^{1}$, Amin Sheikh Abdirahman ${ }^{1}$, Wuqing Wan ${ }^{1}$ \\ and Chuan Wen ${ }^{1 *}$ \\ ${ }^{1}$ Division of Hematology and Tumor, Children's Medical Center, The Second Xiangya Hospital, Central South University, \\ Changsha, China, ${ }^{2}$ Department of Hepatobiliary Surgery, Sichuan Provincial People's Hospital, Chengdu, China
}

OPEN ACCESS

Edited by:

Fatemeh Momen-Heravi, Columbia University, United States

Reviewed by:

Teresa Zelante,

University of Perugia, Italy

Stefano Ugel,

University of Verona, Italy

*Correspondence:

Chuan Wen

chuanwen@csu.edu.cn

†These authors have contributed equally to this work

Specialty section: This article was submitted to Immunological Tolerance and Regulation,

a section of the journal

Frontiers in Immunology

Received: 15 June 2019 Accepted: 06 January 2020 Published: 11 February 2020

Citation:

Xie M, Xiong W, She Z, Wen Z, Abdirahman AS, Wan $W$ and Wen $C$ (2020) Immunoregulatory Effects of

Stem Cell-Derived Extracellular

Vesicles on Immune Cells.

Front. Immunol. 11:13.

doi: 10.3389/fimmu.2020.00013
Recent investigations on the regulatory action of extracellular vesicles (EVs) on immune cells in vitro and in vivo have sparked interest on the subject. As commonly known, EVs are subcellular components secreted by a paracellular mechanism and are essentially a group of nanoparticles containing exosomes, microvesicles, and apoptotic bodies. They are double-layer membrane-bound vesicles enriched with proteins, nucleic acids, and other active compounds. EVs are recognized as a novel apparatus for intercellular communication that acts through delivery of signal molecules. EVs are secreted by almost all cell types, including stem/progenitor cells. The EVs derived from stem/progenitor cells are analogous to the parental cells and inhibit or enhance immune response. This review aims to provide its readers a comprehensive overview of the possible mechanisms underlying the immunomodulatory effects exerted by stem/progenitor cell-derived EVs upon natural killer (NK) cells, dendritic cells (DCs), monocytes/macrophages, microglia, T cells, and B cells.

Keywords: extracellular vesicle, microvesicle, exosome, stem/progenitor cell, immune cell, immunoregulatory

\section{INTRODUCTION}

Extracellular vesicles (EVs), now identified as a novel apparatus of intercellular communication, did not garner significant attention previously, although they are currently sought after as a topic of research. EVs have a diameter ranging between 50 and 2,000 $\mathrm{nm}$ with a bilayer lipid membrane (1) and comprise parental cell-derived active cargos such as lipids (2), proteins $(2,3)$, nucleic acids [(DNAs) (4), mRNA $(5,6)$, microRNAs (miRNAs) (4), non-coding RNAs (7)] and organelles $(4,8)$. Emerging evidence indicates that double-stranded DNA, DNA-binding histones, and certain miRNAs are not associated with small EVs such as exosomes (9). These inclusions are attached to EV membranes or included within the vesicles (10-12). The components of EVs vary with environmental conditions, cell origin, and cell activation conditions. Moreover, EVs demonstrate significant age-dependent differences in their pro-inflammatory miRNA profile (12). To date, most cell types [including stem cells (SCs)/progenitor cells] have been shown to release specific EVs (13-15), and a growing body of evidence indicates that EVs derived from stem/progenitor cells contribute to immunomodulation responses (16). EVs are detected in all body fluids and serve as a basis for liquid biopsy (17). This review focuses on the mechanisms underlying the immunoregulatory effects exerted by stem/progenitor cell-derived EVs on natural killer (NK) cells, dendritic cells (DCs), monocytes/macrophages, microglia, T cells, and B cells. Defining the mechanism of action of SC-derived EVs (SC-EVs) will facilitate development of novel therapeutic 
approaches on the basis of the synergistic effects of EVs with other beneficial molecules or drugs with complementary effects.

\section{BIOLOGICAL PROPERTIES OF EXTRACELLULAR VESICLES}

An increasing number of studies report the process of secretion of EVs by various cells $(15,18)$. A large number of protuberances and pits on the membrane surface of viable SCs are observed to be dynamic; the protuberances may shed as microvesicles (MVs), and the pits may form when multivesicular bodies (MVBs) fuse with the plasma membrane to release exosomes (18).

EVs are classified into three main categories on the basis of their size and biogenesis: (1) Exosomes (50-120 nm) are produced through the inward invagination of the endosomal membrane. First, the inward budding of the plasma membrane leads to formation of the early endosome, followed by formation of intraluminal vesicles (ILVs) by inward budding of the limiting membrane inside MVBs, followed by release of ILVs from MVBs to the extracellular space after fusing with the plasma membrane, leading to formation of exosomes (1). Biogenesis within endosomes (now known as MVBs) is distinctive to exosomes. (2) MVs (200-2,000 nm) develop as membrane protrusions and eventually form bulges that detach directly (17). (3) Apoptotic bodies (Abs) (500-2,000 nm) characterized by the presence of organelles within the membrane enclosed vesicles released by cells undergoing apoptosis (19). Furthermore, a growing body of evidence suggests that apoptotic cell-derived EVs (ApoEVs) play a significant role in immunomodulation. For example, ApoEVs promote phagocyte recruitment to clear apoptotic cells, present antigen to $\mathrm{T}$ cells, facilitate immune response of DCs, and induce infection $(20,21)$. Thus, SC-EVs may be widely used in treatment of autoimmunity, cancer, and infection in the future. Limited information is available about the functional significance of ApoEVs, apart from its role in fragmentation of cells undergoing apoptosis and the immunomodulatory activities of other cell-derived ApoEVs (21). Therefore, we focus on the immunomodulatory effects of SC exosomes and SC-MVs in our review.

Owing to the overlap in size and density, the term "EVs" usually refers to exosomes and MVs. Intercellular communication is achieved through a variety of pathways, such as cell-cell contact (22), tunnel nanotubes (23), and paracrine mechanisms. Research has indicated that EVs transfer signaling molecules from one cell to another cell or into various body fluids through a paracrine mechanism, thus regulating the gene expression and phenotypic transformation of target cells through a continuous secretion-uptake process. Therefore, EVs are significant as information vehicles. EVs are taken up by target cells through direct membrane fusion, receptor-mediated phagocytosis, and several other internalized mechanisms (24), leading to subsequent activation of signal transduction pathways $(14,25)$ and involvement in various physiological and pathological processes in vivo, such as immune response and cell phenotypic transformation.

\section{BIDIRECTIONAL INTERACTION OF STEM CELLS WITH IMMUNE CELLS THROUGH THEIR RESPECTIVE EXTRACELLULAR VESICLES}

SCs are capable of self-renewal and indefinite proliferation, participating in maintenance of cell cycle, tissue repair and regeneration, and immune response regulation. SC-EVs are internalized by target cells primarily through specific receptorligand interaction modes to exert biological functions (26-28). Intercellular communication between SCs and immune cells is achieved through their respective EVs. For example, SCEVs internalized by immune cells inhibit the proliferation and activation of the latter $(29,30)$ (Figure 1). SC-EVs preferentially accumulate in injury sites to inhibit the pro-inflammatory response of immune cells (31). EVs derived from immune cells are also internalized by SCs to promote recruitment and migration of SCs (32) (Figure 1). Additionally, immune cells and tumoral SCs have been observed to restrict each other through EVs. For example, activated CD8+ T cellderived EVs were observed to prevent tumor progression by EV-mediated depletion of mesenchymal stromal/stem cells (MSCs) associated with tumor expansion in tumor environment (33). Glioblastoma SCs (GSCs)-derived EVs induced inclination of human monocytes toward the immunosuppressive M2 phenotype expressing programmed death ligand-1 (PD-L1), leading to the spread of tumor cells (34). Overall, the bidirectional interaction of EVs secreted by SCs and by immune cells has provided a theoretical basis for exploring tissue/organ repair and antitumor mechanisms. In this review, we focus on the regulatory potential of SC-EVs on immune cells.

\section{IMMUNOMODULATORY POTENTIAL OF STEM CELL-DERIVED EXTRACELLULAR VESICLES ON IMMUNE CELLS}

\section{Natural Killer Cells}

SC-EVs primarily exert immunosuppressive effects on NK cells, including recruitment, proliferation, activation, and release of cytotoxic substances. For example, human umbilical cord MSC-derived EVs (hUC-MSC-EVs) demonstrated a protective role in rats with renal ischemia-reperfusion injury through downregulation of the renal expression of C-X3-C motif chemokine ligand-1 (CX3CL1) and toll-like receptor-2 (TLR2 ), and transfer of various miRNAs, thus inhibiting the CD3CD161+NK infiltration (35) (Table 1). In an experiment on human graft-vs.-host disease (GVHD), MSC exosomes were shown to reduce the release of interferon gamma (IFN- $\gamma$ ) and tumor necrosis factor alpha (TNF- $\alpha$ ) by activated NK cells, alleviating the inflammatory response (100). In addition, the anti-inflammatory molecules contained in MSC exosomes, such as interleukin 10 (IL-10), transforming growth factor- $\beta 1$ (TGF$\beta 1$ ), and human leukocyte antigen-G (HLA-G), are also believed to exert immunoprotective effects (100). Human fetal liver MSC-EVs have been reported to inhibit the proliferation and activation of CD56-dim/CD56-bright NK cells and to suppress 




FIGURE 1 | Bidirectional interaction between stem cells and immune cells through their respective EVs. By delivering proteins, nucleic acids, organelles, etc., EVs released from stem cells may inhibit the proliferation, differentiation, and activation of the immune cells to induce immunotolerance. Conversely, EVs released from immune cells may motivate the migration and recruitment of stem cells to promote tissue repair. EVs, extracellular vesicles; SCs, stem cells; ICs, immune cells.

the cytotoxic degranulation capacity of NK cells on target cells in vitro (95). A possible mechanism by which MSC-EVs exert these immunomodulatory effects on NK cells could be through the TGF- $\beta$ expression on their membranes mediating downstream TGF/Smad2/3 signaling (95) (Table 1). These findings suggest that SC-EVs play a therapeutic role in suppressing the lethality of NK cells, which serves as a theoretical basis for disease treatment or drug development.

\section{Dendritic Cells}

DCs are classic antigen-presenting cells (APCs) with a significant role in adaptive immune response. DCs internalize and process antigens, followed by upregulation of the expression of class II major histocompatibility complex (MHC II) and $\mathrm{T}$ cell costimulatory molecules (CD80 and CD86) on their surfaces. The processed antigens are then docked onto MHC II molecules, leading to their transformation into APCs and conversion from immature DCs (iDCs) to mature DCs (mDCs) (101).

SC-EVs have been observed to exert immunosuppressive effects on DCs primarily through inhibition of DC maturation and activation, which hardly affects the proliferation and apoptosis of DCs (60-62, 77, 96, 97). For example, SCEVs were observed to indirectly inhibit the immune response of $\mathrm{T}$ cells by inducing production of immature IL-10secreting DCs through downregulation of MHC class II and/or costimulatory molecule expression on the surface of DCs $(77,97)$. One possible mechanism of action mediated by SC-EVs is to upregulate micro-146a expression, downregulate FAS gene expression in DCs, and induce production of an immature phenotype of DCs, followed by inhibition of IL12 production (60) (Table 1). Another possible mechanism might be related to the immunosuppressive effect exerted by SC-EVs enabled by upregulation of anti-inflammatory HLA-G molecule expression on SC-EVs (96) (Table 1). In addition, the biological effect of EVs reportedly depends on the engineered SCs. For instance, exosomes secreted by indoleamine-2,3dioxygenase-1 (IDO1)-overexpressing rat bone marrow MSCs (BM-MSCs) increased the expression of both miR-540-3p and immunoregulatory protein FHL-1 and induced production of a low-activity phenotype of DCs, thus inhibiting the proliferation of T cells (61) (Table 1). In other words, SC-EVs suppressed the ability of APCs to create an immunotolerant environment that is advantageous for graft survival (60) and tumor cell escape (96). Investigation of the beneficial or harmful effects of SC-EVs facilitates the understanding of biological mechanisms of diseases and possible methods for controlling them. 
TABLE 1 | Immunoregulatory potential and mechanism of SC-EVs on immune cells.

\begin{tabular}{|c|c|c|c|c|c|c|}
\hline $\begin{array}{l}\text { SC type } \\
\text { releasing EVs }\end{array}$ & Models & $\begin{array}{l}\text { Transferring } \\
\text { materials }\end{array}$ & Target cells & $\begin{array}{l}\text { Molecular } \\
\text { mechanisms }\end{array}$ & Biological effects & References \\
\hline hUC-MSCs & Renal IRI rat model & miRNAs & Injured kidney & $\begin{array}{l}\text { Downregulate TLR-2 and } \\
\text { CX3CL1 }\end{array}$ & $\begin{array}{l}\text { Promote NK cell suppression } \\
\text { and ameliorate renal } \\
\text { ischemia-reperfusion injury }\end{array}$ & (35) \\
\hline hUC-MSCs & $\begin{array}{l}\text { Severe burn rat } \\
\text { model }\end{array}$ & $\mathrm{miR}-181 \mathrm{c}$ & Macrophages & $\begin{array}{l}\text { Inhibit NF-kB/p-P65 signal } \\
\text { pathway }\end{array}$ & $\begin{array}{l}\text { Reduce macrophage } \\
\text { activation and alleviate } \\
\text { burn-induced inflammation }\end{array}$ & (36) \\
\hline hUC-MSCs & AAA mice model & $\operatorname{miR}-147$ & Macrophages & - & $\begin{array}{l}\text { Induce M1 suppression in } \\
\text { aortic smooth muscle cells } \\
\text { and mitigate AAA formation }\end{array}$ & (38) \\
\hline $\begin{array}{l}\text { hUC-MSCs } \\
\text { (LPS-pretreated) }\end{array}$ & $\begin{array}{l}\text { Cutaneous wound } \\
\text { of diabetic rat } \\
\text { model }\end{array}$ & Let-7b & Macrophages & $\begin{array}{l}\text { Suppress } \\
\text { TLR4/NF-кB/STAT3/AKT } \\
\text { pathway }\end{array}$ & $\begin{array}{l}\text { Promote M2 induction and } \\
\text { diabetic cutaneous wound } \\
\text { healing }\end{array}$ & (39) \\
\hline hUC-MSCs & $\begin{array}{l}\text { Retinal laser injury } \\
\text { mice model, } \\
\text { EAU rat model }\end{array}$ & - & The retina cells & Downregulate MCP-1 & $\begin{array}{l}\text { Inhibit macrophage infiltration } \\
\text { and protect the retina from } \\
\text { inflammatory injury }\end{array}$ & $(41,42)$ \\
\hline hUC-MSCs & In vitro & $\begin{array}{l}\text { CD73 } \\
\text { expressing }\end{array}$ & T cells & - & $\begin{array}{l}\text { Suppress } T \text { cell } \\
\text { proliferation and induce } \\
\text { immunosuppressive response }\end{array}$ & (11) \\
\hline $\begin{array}{l}\text { hUC-MSCs } \\
\text { (HLA light chain B2M } \\
\text { deletion) }\end{array}$ & $\begin{array}{l}\text { Myocardial } \\
\text { infarction rat model }\end{array}$ & miR-24 & Cardiomyocytes & $\begin{array}{l}\text { B2M-UCMSC- } \\
\text { exosomes/miR-24/Bcl-2- } \\
\text { like protein 11(Bim) } \\
\text { pathway }\end{array}$ & $\begin{array}{l}\text { Inhibit CD8+ immune } \\
\text { rejection and cardiomyocytes } \\
\text { apoptosis }\end{array}$ & (43) \\
\hline hUC-MSCs & GVHD mice model & - & CD8+ T, Th cells & - & $\begin{array}{l}\text { Suppress CD8+ T cells, } \\
\text { switch the immune response } \\
\text { from Th1 cells to Th2, prevent } \\
\text { life-threatening GVHD after } \\
\text { allo-HSCT }\end{array}$ & (44) \\
\hline hUC-MSCs & $\begin{array}{l}\text { Perinatal brain } \\
\text { injury rat model }\end{array}$ & - & Microglia & $\begin{array}{l}\text { Suppress TLR4/CD14 } \\
\text { signaling pathway } \\
\text { (NF-kB/MAPK family } \\
\text { members ERK1/2, p38, and } \\
\text { JNK) }\end{array}$ & $\begin{array}{l}\text { Prevent and treat perinatal } \\
\text { brain injury }\end{array}$ & (46) \\
\hline $\begin{array}{l}\text { hAD-MSCs } \\
\text { (hypoxic pretreated) }\end{array}$ & $\begin{array}{l}\text { Skeletal muscle } \\
\text { injury mice model }\end{array}$ & - & Injured muscle cells & Upregulate CCL2 & $\begin{array}{l}\text { Increase M2 macrophage } \\
\text { infiltration and promote M2 } \\
\text { induction and injury site } \\
\text { recovery }\end{array}$ & (47) \\
\hline $\begin{array}{l}\text { hAD-MSCs } \\
\text { (IFN- } \gamma \text { stimulated) }\end{array}$ & In vitro & - & $\begin{array}{l}\text { CD14+CD16+ } \\
\text { Monocytes }\end{array}$ & - & $\begin{array}{l}\text { Induce apoptosis of the } \\
\text { targets cells }\end{array}$ & (48) \\
\hline hAD-MSCs & $\begin{array}{l}\text { Experimental } \\
\text { allergic } \\
\text { asthma mice model }\end{array}$ & - & T cells & - & $\begin{array}{l}\text { Switch the immune response } \\
\text { from Th2 cells to Th1 and } \\
\text { reduce inflammation and } \\
\text { tissue remodeling }\end{array}$ & (49) \\
\hline mAD-MSCs & ALF mice model & miR-17 & Macrophages & $\begin{array}{l}\text { Inhibit TXNIP/NLRP3 } \\
\text { inflammasome }\end{array}$ & $\begin{array}{l}\text { Reduce macrophage } \\
\text { activation and improve liver } \\
\text { function }\end{array}$ & (50) \\
\hline
\end{tabular}


TABLE 1 | Continued

\begin{tabular}{|c|c|c|c|c|c|c|}
\hline $\begin{array}{l}\text { SC type } \\
\text { releasing EVs }\end{array}$ & Models & $\begin{array}{l}\text { Transferring } \\
\text { materials }\end{array}$ & Target cells & $\begin{array}{l}\text { Molecular } \\
\text { mechanisms }\end{array}$ & Biological effects & References \\
\hline mAD-MSCs & T1D mice model & - & T cells & - & $\begin{array}{l}\text { Regulate the immune } \\
\text { response axis of Th17/Tregs } \\
\text { and prevent T1D progressing }\end{array}$ & (51) \\
\hline mAD-MSC & In vitro & - & $\begin{array}{l}\text { Macrophages, DCs, } \\
\text { Th2 cells }\end{array}$ & - & $\begin{array}{l}\text { Promote M2 polarization and } \\
\text { DC maturation to ameliorate } \\
\text { Th2-mediated inflammation } \\
\text { response }\end{array}$ & (52) \\
\hline mAD-SCs & $\begin{array}{l}\text { Diet-induced } \\
\text { obesity mice model }\end{array}$ & $\begin{array}{l}\text { Phosphorylated } \\
\text { STAT3 }\end{array}$ & Macrophages & - & $\begin{array}{l}\text { M2 induction in WAT and } \\
\text { improve systemic metabolic } \\
\text { homeostasis }\end{array}$ & (53) \\
\hline mAD-SCs & EAE mice model & - & T cells & $\begin{array}{l}\text { Inhibit integrin-dependent } \\
\text { chemokine pathway }\end{array}$ & $\begin{array}{l}\text { Suppress activated T cell } \\
\text { adhesion and ameliorate } \\
\text { chronic inflammation }\end{array}$ & (54) \\
\hline rAD-SCs & In vitro & - & Microglia & $\begin{array}{l}\text { Inhibit NF-кB/MAPK family } \\
\text { member signaling pathway }\end{array}$ & $\begin{array}{l}\text { Decrease cytotoxicity of } \\
\text { activated microglia }\end{array}$ & (57) \\
\hline $\begin{array}{l}\text { rAD-SCs } \\
\text { miRNA-126-modified }\end{array}$ & Stroke rat model & miRNA-126 & Microglia & - & Treatment for stroke & (58) \\
\hline $\begin{array}{l}\text { rAD-SCs } \\
\text { (overexpressed } \\
\text { miR-30d-5p) }\end{array}$ & $\begin{array}{l}\text { Acute ischemic } \\
\text { stroke rats model }\end{array}$ & miR-30d-5p & Microglia & $\begin{array}{l}\text { Suppress the expression of } \\
3^{\prime} \text { UTR of both Beclin-1 and } \\
\text { Atg5 }\end{array}$ & $\begin{array}{l}\text { Inhibit microglial polarization } \\
\text { to } \mathrm{M} 1 \text { and decrease the } \\
\text { cerebral injury area of } \\
\text { infarction }\end{array}$ & (59) \\
\hline mBM-MSCs & $\begin{array}{l}\text { Allogeneic kidney } \\
\text { graft mice model }\end{array}$ & Micro-146a & DCs & - & $\begin{array}{l}\text { Inhibit DC maturation, } \\
\text { promote allogeneic kidney } \\
\text { graft survival }\end{array}$ & (60) \\
\hline mBM-MSCs & $\begin{array}{l}\mathrm{ApoE}^{-/-} \\
\text {atherosclerosis } \\
\text { mice model }\end{array}$ & miR-let7 & Macrophages & $\begin{array}{l}\text { Suppress IGF2BP1/PTEN } \\
\text { pathway in the plaque }\end{array}$ & $\begin{array}{l}\text { Reduce macrophage } \\
\text { infiltration to meliorate } \\
\text { atherosclerosis }\end{array}$ & (63) \\
\hline mBM-MSCs & $\begin{array}{l}\text { Cardiomyocyte } \\
\text { injury in } \\
\text { polymicrobial } \\
\text { sepsis mice model }\end{array}$ & miR-223 & $\begin{array}{l}\text { Macrophages, } \\
\text { cardiomyocyte }\end{array}$ & $\begin{array}{l}\text { Downregulate expression of } \\
\text { Stat3 and Sema3A proteins }\end{array}$ & $\begin{array}{l}\text { Attenuate inflammatory } \\
\text { response and exert } \\
\text { cardioprotection }\end{array}$ & (64) \\
\hline rBM-MSCs & In vitro & - & Macrophages & $\begin{array}{l}\text { Target AKT1/AKT2 } \\
\text { signaling pathway and } \\
\text { suppress the NF-KB } \\
\text { signaling pathway }\end{array}$ & $\begin{array}{l}\text { M2 induction and alleviate } \\
\text { inflammation }\end{array}$ & (65) \\
\hline hBM-MSCs & ARDS mice model & $\begin{array}{l}\text { Functional } \\
\text { mitochondria }\end{array}$ & Macrophages & $\begin{array}{l}\text { Enhance macrophage } \\
\text { oxidative phosphorylation }\end{array}$ & $\begin{array}{l}\text { M2 induction and ameliorate } \\
\text { lung injury }\end{array}$ & (8) \\
\hline mBM-MSCs & In vitro & - & Macrophages & $\begin{array}{l}\text { Downregulate expression of } \\
\text { CCR7 }\end{array}$ & $\begin{array}{l}\text { Promote M2 induction } \\
\text { and guide immunotolerance }\end{array}$ & (27) \\
\hline mBM-MSCs & $\begin{array}{l}\text { ApoE- }{ }^{-/-} \\
\text {atherosclerosis } \\
\text { mice model }\end{array}$ & miR-let7 & Macrophages & $\begin{array}{l}\text { Inhibit HMGA2/NF-кB signal } \\
\text { pathway }\end{array}$ & $\begin{array}{l}\text { M2 induction and ameliorate } \\
\text { atherosclerosis }\end{array}$ & (63) \\
\hline
\end{tabular}


TABLE 1 | Continued

\begin{tabular}{|c|c|c|c|c|c|c|}
\hline $\begin{array}{l}\text { SC type } \\
\text { releasing EVs }\end{array}$ & Models & $\begin{array}{l}\text { Transferring } \\
\text { materials }\end{array}$ & Target cells & $\begin{array}{l}\text { Molecular } \\
\text { mechanisms }\end{array}$ & Biological effects & References \\
\hline $\begin{array}{l}\text { hBM-MSCs } \\
\text { (Hypoxia } \\
\text { prechallenged) }\end{array}$ & $\begin{array}{l}\text { Non-small cell lung } \\
\text { cancer cell } \\
\text { xenograft mice } \\
\text { model }\end{array}$ & $m i R-21-5 p$ & Macrophages & $\begin{array}{l}\text { Downregulate expression of } \\
\text { PTEN gene and promote } \\
\text { p-Akt/p-STAT3 signal } \\
\text { pathway }\end{array}$ & $\begin{array}{l}\text { M2 induction and promote } \\
\text { non-small-cell lung cancer } \\
\text { cells growth and mobility }\end{array}$ & (66) \\
\hline mBM-MSCs & $\begin{array}{l}\text { Dilated } \\
\text { cardiomyopathy } \\
\text { mice model }\end{array}$ & - & Macrophages & $\begin{array}{l}\text { Activate JAK2-STAT6 signal } \\
\text { pathway }\end{array}$ & $\begin{array}{l}\text { Promote M2 induction } \\
\text { and ameliorate myocardial } \\
\text { inflammation }\end{array}$ & (67) \\
\hline mBM-MSCs & $\begin{array}{l}\text { Myocardial IRI } \\
\text { mouse model }\end{array}$ & miR-182 & Macrophages & $\begin{array}{l}\text { Target } \\
\text { TLR4/NF- } \kappa \text { B/PI3K/Akt } \\
\text { pathway }\end{array}$ & $\begin{array}{l}\text { Promote M2 induction and } \\
\text { attenuate myocardial IRI }\end{array}$ & (68) \\
\hline mBM-MSC & $\begin{array}{l}\text { Ulcerative colitis } \\
\text { mice model }\end{array}$ & - & Macrophages & $\begin{array}{l}\text { Target JAK1/STAT1/ } \\
\text { STAT6 signaling pathway }\end{array}$ & $\begin{array}{l}\text { M2 induction and exert } \\
\text { therapeutic effects }\end{array}$ & (69) \\
\hline hBM-MSCs & $\begin{array}{l}\text { Skin wound-healing } \\
\text { mice model }\end{array}$ & miR-223 & Macrophages & Target pknox1 & $\begin{array}{l}\text { M2 induction and accelerate } \\
\text { wound healing }\end{array}$ & (70) \\
\hline hBM-MSC & $\begin{array}{l}\text { Cerebral apoplexy } \\
\text { rat model and } \\
\text { stroke mice model }\end{array}$ & - & $\begin{array}{l}\text { T cells, B cells, } \\
\text { NK cells }\end{array}$ & - & $\begin{array}{l}\text { Attenuate T cell, B cell, and } \\
\text { NK cell lymphopenia and } \\
\text { prevent postischemic } \\
\text { immunosuppression }\end{array}$ & $(72,73)$ \\
\hline mBM-MSCs & $\begin{array}{l}\text { Inflammatory } \\
\text { arthritis mice model }\end{array}$ & - & $\mathrm{T}$ cells & - & $\begin{array}{l}\text { Switch the immune response } \\
\text { from Th1 cells to Th2 to } \\
\text { therapy the arthritis }\end{array}$ & (29) \\
\hline hBM-MSCs & In vitro & - & $\mathrm{T}$ cells & - & $\begin{array}{l}\text { Induce conversion of Th1 into } \\
\text { Th2 cells }\end{array}$ & (74) \\
\hline hBM-MSCs & T1D patient & - & DCs, T cells & - & $\begin{array}{l}\text { Induce DC immaturity, inhibit } \\
\text { differentiation of Th1 and } \\
\text { Th17 cells, increase Tregs to } \\
\text { induce immunotolerance }\end{array}$ & (77) \\
\hline mBM-MSCs & $\begin{array}{l}\text { Tight-skin mice } \\
\text { model }\end{array}$ & miR-151-5p & $\begin{array}{l}\text { The recipient } \\
\text { BM-MSCs, Th2 cells }\end{array}$ & $\begin{array}{l}\text { Suppress IL4R } \alpha / m T O R \\
\text { pathway }\end{array}$ & $\begin{array}{l}\text { Inhibit Th2 cell immune } \\
\text { response to therapy systemic } \\
\text { sclerosis }\end{array}$ & (78) \\
\hline hBM-MSCs & $\begin{array}{l}\text { Human-into mouse } \\
\text { xenogeneic GVHD } \\
\text { model }\end{array}$ & $\begin{array}{l}\text { Adenosine } \\
\text { signaling }\end{array}$ & Th1 cells & - & $\begin{array}{l}\text { Induce the apoptosis of Th1 } \\
\text { cells and promote immune } \\
\text { suppression }\end{array}$ & (79) \\
\hline hBM-MSCs & In vitro & - & B cells & $\begin{array}{l}\text { Affect mRNA expression of } \\
\text { B cells }\end{array}$ & $\begin{array}{l}\text { Inhibit the proliferation and } \\
\text { function of B-lymphocytes }\end{array}$ & (80) \\
\hline $\begin{array}{l}\text { hBM-MSC } \\
\text { (IFN- } \gamma \text { and TNF- } \alpha \\
\text { pretreated) }\end{array}$ & In vitro & miR-155-5p & B cells & $\begin{array}{l}\text { Downregulation of } \\
\text { PI3K-AKT signaling pathway } \\
\text { and modulation of the } \\
\text { reorganization of actin } \\
\text { cytoskeleton }\end{array}$ & $\begin{array}{l}\text { Inhibit the proliferation and } \\
\text { activation of B cells }\end{array}$ & (81) \\
\hline hBM-MSCs & In vitro & - & CLL B cells & $\begin{array}{l}\text { Induce gene expression } \\
\text { profile modifications }\end{array}$ & Promote the CLL progress & (82) \\
\hline
\end{tabular}


TABLE 1 | Continued

\begin{tabular}{|c|c|c|c|c|c|c|}
\hline $\begin{array}{l}\text { SC type } \\
\text { releasing EVs }\end{array}$ & Models & $\begin{array}{l}\text { Transferring } \\
\text { materials }\end{array}$ & Target cells & $\begin{array}{l}\text { Molecular } \\
\text { mechanisms }\end{array}$ & Biological effects & References \\
\hline $\begin{array}{l}\text { mBM-MSCs } \\
\text { (Irradiated) }\end{array}$ & $\begin{array}{l}\text { Inflammatory } \\
\text { arthritis mice } \\
\text { model, } \\
\text { osteoarthritis mice } \\
\text { model }\end{array}$ & - & $\begin{array}{l}\text { B cells, } \\
\text { plasma cells }\end{array}$ & - & $\begin{array}{l}\text { Repress the activation of B } \\
\text { cells, inhibit plasma cell } \\
\text { differentiation, and induce } \\
\text { IL-10-expressing Breg cells } \\
\text { and exert therapeutic effects }\end{array}$ & $(29,83)$ \\
\hline mBM-MSCs & In vitro & - & Microglia & $\begin{array}{l}\text { Suppress phosphorylation } \\
\text { of ERK } 1 / 2 \text {, JNK, and p38 } \\
\text { molecules }\end{array}$ & $\begin{array}{l}\text { Inhibit the activation of } \\
\text { microglia }\end{array}$ & (85) \\
\hline $\begin{array}{l}\text { hAF-SCs } \\
\text { (IFN- } \gamma \text { treated) }\end{array}$ & $\begin{array}{l}\text { Allograft mice } \\
\text { model }\end{array}$ & IDO1 proteins & $\mathrm{T}$ cells & - & $\begin{array}{l}\text { Decrease T cell proliferation, } \\
\text { increase Tregs, and promote } \\
\text { allograft survival }\end{array}$ & (88) \\
\hline mESCs & $\begin{array}{l}\text { Cardiomyopathy } \\
\text { mice model }\end{array}$ & - & Macrophages & $\begin{array}{l}\text { Suppress phosphorylation } \\
\text { of MyD88, P38, and JNK } \\
\text { molecules }\end{array}$ & $\begin{array}{l}\text { M2 induction and reduce } \\
\text { doxorubicin-induced } \\
\text { pyroptosis and cardiac } \\
\text { remodeling }\end{array}$ & (89) \\
\hline mESCs & $\begin{array}{l}\text { Implanted lung } \\
\text { adenocarcinoma } \\
\text { mice model }\end{array}$ & $\begin{array}{l}\text { GM-CSF- } \\
\text { expressing }\end{array}$ & CD8+ T cells, Tregs & - & $\begin{array}{l}\text { Increase CD8+ T cells, } \\
\text { inhibit Tregs in tumor, activate } \\
\text { CD8+ effector cells within the } \\
\text { tumors, prophylactic vaccine } \\
\text { for cancer prevention }\end{array}$ & (90) \\
\hline cWJ-MSCs & In vitro & $\begin{array}{l}\text { TGF- } \beta \text {, } \\
\text { adenosine } \\
\text { signaling }\end{array}$ & T cells & - & $\begin{array}{l}\text { Inhibit CD4 +T cells } \\
\text { proliferation }\end{array}$ & (92) \\
\hline $\begin{array}{l}\text { hPDL-SCs } \\
\text { (LPS-pretreated) }\end{array}$ & In vitro & DNA & Macrophages & - & M1 induction & (93) \\
\hline $\begin{array}{l}\text { hPDL-SCs } \\
\text { (LPS-stimulated) }\end{array}$ & $\begin{array}{l}\text { Chronic } \\
\text { periodontitis }\end{array}$ & miR-155-5p & T cells & Target sirtuin-1 & $\begin{array}{l}\text { Regulate the immune } \\
\text { response axis of Th17/Tregs } \\
\text { and reduce the further } \\
\text { deterioration of periodontitis }\end{array}$ & (94) \\
\hline hFL-MSCs & In vitro & TGF- $\beta$ & NK cells & $\begin{array}{l}\text { Inhibit the nuclear } \\
\text { translocation of } \\
\text { phosphorylated Smad2/3 in } \\
\text { TGF/Smad pathway }\end{array}$ & Impair NK cells function & (95) \\
\hline rCD105(+) renal CSCs & In vitro & HLA-G & DCs, T cells & - & $\begin{array}{l}\text { Inhibit DC maturity, indirectly } \\
\text { regulate T cell immune } \\
\text { response, promote cancer } \\
\text { progression }\end{array}$ & (96) \\
\hline h-end-MSCs & In vitro & TGF- $\beta$ & T cells & - & $\begin{array}{l}\text { Suppress CD4+ T cell } \\
\text { activation }\end{array}$ & (10) \\
\hline
\end{tabular}


TABLE 1 | Continued

\begin{tabular}{|c|c|c|c|c|c|c|}
\hline $\begin{array}{l}\text { SC type } \\
\text { releasing EVs }\end{array}$ & Models & $\begin{array}{l}\text { Transferring } \\
\text { materials }\end{array}$ & Target cells & $\begin{array}{l}\text { Molecular } \\
\text { mechanisms }\end{array}$ & Biological effects & References \\
\hline hNSCs & $\begin{array}{l}\text { Thromboembolic } \\
\text { stroke murine } \\
\text { model }\end{array}$ & - & Macrophages, T cells & - & $\begin{array}{l}\text { Regulate the immune } \\
\text { response axis of Th17/Tregs } \\
\text { and exert } \\
\text { therapeutic effects and } \\
\text { improve prognosis }\end{array}$ & (31) \\
\hline $\begin{array}{l}\text { hMSCs } \\
\text { (protein-free medium } \\
\text { activated) }\end{array}$ & $\begin{array}{l}\text { T1D and } \\
\text { uveoretinitis murine } \\
\text { model }\end{array}$ & - & DCs, T cells & - & $\begin{array}{l}\text { Induce DC immaturity and } \\
\text { inhibit Th1 and Th17 cells to } \\
\text { balance immune responses }\end{array}$ & (97) \\
\hline hGSCs & In vitro & - & $\begin{array}{l}\text { CD14+ monocytes, } \\
\text { T cells }\end{array}$ & - & $\begin{array}{l}\text { Involved in the conversion of } \\
\text { monocyte phenotypes and in } \\
\text { inhibition of T cell immune } \\
\text { response }\end{array}$ & (98) \\
\hline $\begin{array}{l}\text { iPSC-MSCs } \\
\text { (protein-free medium } \\
\text { activated) }\end{array}$ & $\begin{array}{l}\text { Sjögren's syndrome } \\
\text { mouse model }\end{array}$ & - & APCs, $T$ cells & - & $\begin{array}{l}\text { Inhibit Tfh and Th17 cells and } \\
\text { prevent SS progression }\end{array}$ & (99) \\
\hline
\end{tabular}

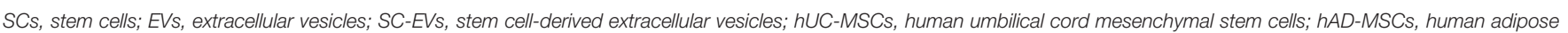



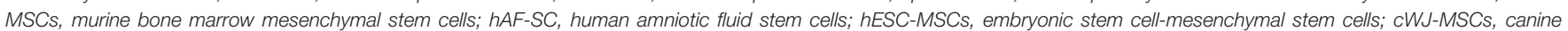

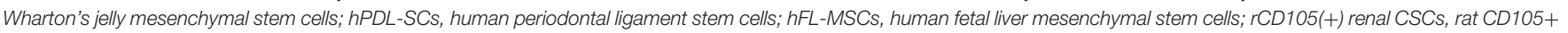

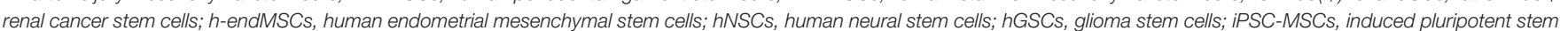

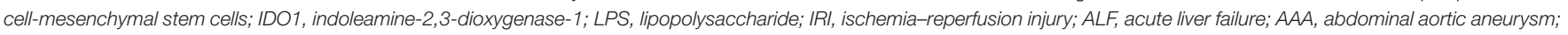

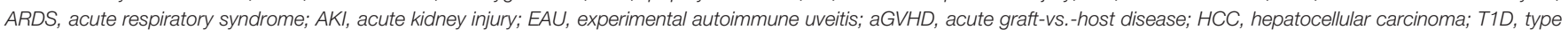



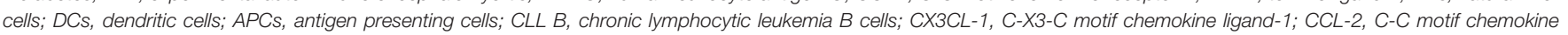



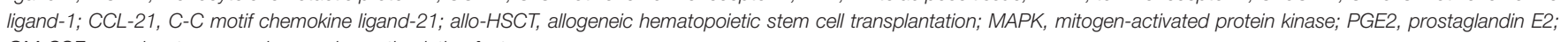
GM-CSF, granulocyte-macrophage colony-stimulating factor.

\section{Macrophages/Monocytes} Effects of Stem Cell-Derived Extracellular Vesicles on Macrophage Polarization and Homeostasis

SC-EVs have been shown to polarize macrophages to the alternate phenotype. On the one hand, SC-EVs directly or indirectly inhibit the inflammatory reaction of macrophages. For example, (1) SC-EVs directly act on pro-inflammatory macrophages by inhibiting their infiltration (63) (Table 1) and activation $(36-38,50,64)$ (Table 1 ) and by regulating their phenotype polarization from pro-inflammatory M1 toward anti-inflammatory M2, facilitating low expression of proinflammatory molecules IFN- $\gamma$ and TNF- $\alpha$; contrarily, they enhance the expression of anti-inflammatory molecule IL-10 to induce immunotolerance $(6,8,27,39,40,53,55,63,65-$ 70, 87, 89) (Table 1). (2) SC-EVs express chemokine receptors (26) (Table 1) and indirectly promote the infiltration of antiinflammatory M2 macrophages (47) or prevent the migration of pro-inflammatory M1 macrophages through interaction with chemokine ligands expressed on other tissues and cells (28, 41, 42, 47) (Table 1). In addition, as reported by a study, SC-EVs downregulate the production of IL-23 and IL-22 and upregulate anti-inflammatory prostaglandin E2 (PGE2) by indirectly repressing the function of $\mathrm{T}$ helper type 17 (Th17) cell or by inducing conversion of Th17 cells into regulatory $\mathrm{T}$ cells (Tregs) (102). As a result, SC-EVs induced conversion of activated regulatory macrophages (Mregs) from a proinflammatory phenotype to an alternative anti-inflammatory phenotype and eventually promoted the reduction of severe inflammation (102). On the other hand, SC-EVs also promote inflammatory reactions of macrophages. For example, the DNA in the outer membrane of EVs derived from lipopolysaccharide (LPS)-preconditioned periodontal ligament SCs (PDL-SCs) synergized with peripheral environmental IFN- $\gamma$ to promote M1 polarization of macrophages and expression of high levels of pro-inflammatory molecules IL-6 and TNF- $\alpha$, resulting in teeth damage (93) (Table 1). This finding suggests that the EV-bound DNA might be a potential therapeutic target for periodontitis. A study on a mice model with silicosis that focused on the doubleedged effect of SC-EVs on macrophages using different cargos within EVs revealed notable details. The study showed that MSC transferred mitochondria and miRNAs to human macrophages using MSC-MVs and MSC exosomes, respectively (4). MSCs donated their mitochondria to macrophages to enhance the bioenergetics of macrophages though MV-mediated transfer under oxidative stress. However, MSC-exosome-transferred miRNAs were responsible for targeting MYD88-dependent inflammatory centers to suppress TLR/NF-kB signaling pathway and macrophage activation (4). The dual effect refers to the simultaneous secretion of two types of EVs with different cargos by the SCs to mediate homeostasis. 


\section{Stem Cell-Derived Membrane Particles as Drug Delivery Carrier Targeting of Monocytes}

Membrane particles (MPs) derived from human adipose MSCs (AD-MSCs) were rarely taken up by lymphocytes, although they could selectively bind to and fuse with plasma membrane of monocytes to specifically induce apoptosis of pro-inflammatory CD14+CD16+ monocytes. However, no such effect was exerted on classical CD14+CD16- monocytes (48) (Table 1). Thus, SC-MPs may act as natural drug delivery vehicles targeting monocytes.

\section{Microglia}

As the resident macrophages of the central nervous system (CNS), microglia play a vital role in regulating inflammation, balancing immunity, and promoting development and tissue repair. It is believed that an M1/M2 phenotype imbalance occurs in the CNS diseases and that the polarization of microglia from the M1 to M2 phenotypes can maintain immune homeostasis and neurological function in patients with CNS diseases (103).

\section{Involvement of Neural Stem Cells, Neural Stem Cell-Derived Extracellular Vesicles, and Microglia in Central Nervous System Development}

Microglia are the innate immune cells that play an important physiological role in the nervous system (NS). Neural stem cells (NSCs) and neural stem cell-derived extracellular vesicles (NSC-EVs) are closely associated with microglia during neonatal brain development. For example, the EVs released by neonatal sub-ventricular zone (SVZ)-derived NSCs were observed to contain a variety of miRNAs and preferentially induced a transition of CD11b + microglia to a non-stellate morphology, accompanied by an alteration in the microglial transcriptional state. Conversely, EV-treated neonatal microglia inhibited NSC proliferation by upregulating Let-7-mediated cytokine release (104). Therefore, neonatal NSC-EVs affect the morphology and function of microglia with formation of a negative feedback loop of NSCs that might be conducive to normal development of the NS.

\section{Stem Cell-Derived Extracellular Vesicle Regulatory Potential in Immunoreactive Microglia}

SC-EVs have been observed to regulate the activation of microglia in a variety of NS disease models (46, 57, 58, 85, $86,105)$. For example, MSC-EVs suppressed the activated microglia by inhibiting the phosphorylation of mitogen-activated protein kinase (MAPK) family members extracellular signal kinase 1/2 (ERK1/2), c-Jun N-terminal kinases (JNKs), and the p38 molecules in microglia $(46,57,85)$ (Table 1). Notable studies have reported that BM-MSC exosomes could repair spinal cord injury by suppressing the activation of A1 neurotoxic reactive astrocytes induced by activated microglia (86) or by inhibiting the complement system (105) and the NF- $\kappa \mathrm{B}$ signaling pathway $(46,57,105)$. Meanwhile, SC-EVs have been observed to polarize microglia from classic M1 to antiinflammatory M2 phenotypes $(59,85,106,107)$, which might be attributed to the targeted suppression of the $3^{\prime}$-UTR mRNA expression in Beclin-1 and Atg5 and inhibition of autophagymediated microglial polarization toward pro-inflammatory state by miR-30d-5p-expressing EVs (59) (Table 1). Thus, SC-EVs create a microenvironment conducive to nerve cell repair by inducing expression of microglial immunotolerance phenotypes in NS diseases.

\section{T Cells}

\section{The Diversity of Stem Cell-Derived Extracellular Vesicle Immunoregulatory Potential in T Cells}

The immunoregulatory effects exerted by SC-EVs on activated $\mathrm{T}$ cells remain a widely debated topic. For instance, one study observed that the co-culture of SC-EVs with peripheral blood mononuclear cells (PBMCs) specifically suppressed the proliferation of $\mathrm{T}$ cells, whereas it did not affect that of $\mathrm{B}$ cells and NK cells (71). However, other studies have reported that SCEVs inhibited the proliferation of NK cells and B cells, although its effect on the proliferation of T cells remains unclear $(30,108)$. There are evidences that indicate that SC-EVs do not suppress $\mathrm{T}$ cell proliferation; however, they induce upregulation of Tregs and downregulation of pro-inflammatory cytokines $(51,74,109)$. Results from most studies clearly indicate that SC-EVs indirectly affect $\mathrm{T}$ cells by interaction with macrophages or DCs (110, 111 ); yet limited number of studies have directly examined the suppressive effects of SC-EVs on T cells (112).

\section{Regulatory Potential of Stem Cell-Derived Extracellular Vesicles on T Cells Affected by Different Inflammatory Conditions}

Various inflammatory conditions influence the effects of SCEVs on T cells. For example, exosomes secreted by TGF- $\beta$ and IFN- $\gamma$-conditioned MSCs significantly inhibited PBMCs and effectively promoted differentiation of $\mathrm{T}$ cells into Tregs to alleviate undesirable inflammation, which might be further attributed to upregulation of IL-10, IFN- $\gamma$, and IDO in EVs after exposure to TGF- $\beta$ and IFN- $\gamma$ (113). In addition, MVs secreted by IFN- $\gamma$-conditioned or non-IFN- $\gamma$-conditioned human umbilical cord blood MSCs (UCB-MSCs) exerted similar immunosuppressive effects on $\mathrm{T}$ cells in vitro. However, in mice model with renal ischemic reperfusion, only non-IFN- $\gamma$ conditioned MVs attenuated the inflammatory injury in vivo. Mass spectrometry revealed that the protein content in IFN- $\gamma$ conditioned MVs underwent a significant alteration that might have led to triggering the innate or acquired immune response after inflammatory conditioning. A possible explanation for the above findings could be that the EVs secreted by the same cells under different external conditions originate from different internal vesicle routes (114); for instance, therapeutic MSCEVs originate from the lipid raft microdomain in the plasma membrane (115).

\section{Stem Cell-Derived Extracellular Vesicle Potential in T Cell Proliferation and Activation}

\section{Inhibition of T cells}

It has been demonstrated that SC-EVs carry a variety of active molecules, such as TGF- $\beta(10,92)$, active $\operatorname{CD} 73$ protein $(11,79)$, IDO protein (88), or miR-125a-3p (71). These molecules endow 
SC-EVs with the ability to inhibit $\mathrm{T}$ cell proliferation (11, 71, $88,92,98,112,116,117)$ and activation $(71,76,77,97,98,112$, 116), and preserve the circulating naive T cells (71) (Table 1). Studies have revealed that adenosinergic immunosuppression by SC-EVs required co-operation with $\mathrm{T}$ cells (11), resulting from the presence of adenosine $5^{\prime}$-triphosphate (ATP) in the extracellular environment during in vivo tissue injury. CD73 expressed in EVs has ATPase activity that catalyzes active production of adenosine from adenosine 5 -monophosphate (AMP) (11). Meanwhile, activated T cells expressing CD39 efficiently catalyzed conversion of ATP to AMP (11) (Table 1). Adenosine is highly immunosuppressive. In brief, MSC-EVs suppressed in vitro $\mathrm{T}$ cell proliferation through adenosinergic signaling (11). Recent studies provide evidence that active molecule TGF- $\beta 1$ expressed on SC-EV membrane could synergize with adenosine signaling to suppress the proliferation of CD4+ T cells (92) (Table 1). Advances in SCs technology have provided an interesting perspective on the field of transplantation. For instance, in the rat model of myocardial infarction, beta-2 microglobulin (B2M) negative UC-MSC lost the ability to induce $\mathrm{CD} 8+\mathrm{T}$ cell immune rejection response by the B2M-UCMSC exosomes/miR-24/Bcl-2-like protein 11 (Bim) pathway after B2M-UCMSC injection to the heart (43). The engineered SCs may reveal a novel strategy for tissue repair and regeneration without the requirement for HLA matching. Based on the immunoregulatory effects of SC-EVs on $\mathrm{T}$ cells in vitro and in vivo, these studies have provided guidance for use of SC-EVs therapy in T cell-mediated immune diseases.

\section{Promotion of T cells}

SC-EVs have been shown to promote the proliferation and activation of $\mathrm{T}$ cells. For example, in mice with type 1 diabetes, islet MSC-derived exosomes were observed to activate APCs and autologous $\mathrm{T}$ and $\mathrm{B}$ cells in islets, increase their respective specific memory cells, and induce IFN- $\gamma$ production, thus accelerating islet destruction (118). This evidence provides a perspective that certain SC-EVs serve as autoantigen carriers and trigger autoimmune responses. Additionally, The $\beta$-cateninloading (56) or GM-CSF (granulocyte-macrophage colonystimulating factor)-expressing (90) EVs derived from SCs could promote $\mathrm{T}$ cell antitumor response. For example, the exosomes derived from rat $\mathrm{AD}-\mathrm{MSC}$ s were observed to accelerate intratumoral $\mathrm{CD} 8 \alpha+$ type I NK-T cell migration and increase circulating NK-T cells to exert antitumor immunity in rats with hepatocellular carcinoma (HCC) (56) (Table 1). In mice with transplanted lung adenocarcinoma, exosomes derived from GM-CSF-expressing embryonic SCs (ESCs) were observed to suppress the migration of immunosuppressive Tregs, whereas they reinforced migration of tumor-reactive $\mathrm{CD} 8+\mathrm{T}$ effector cells toward intratumor spaces and elevated intratumoral cytokine responses of TNF- $\alpha$ and IFN- $\gamma$, contributing to the clearance of foreign components (90) (Table 1). Therefore, EVs derived from engineered SCs may be utilized as a preventive vaccine against the risk of cancer development in human beings.

\section{Stem Cell-Derived Extracellular Vesicle Potentials in T Cell Differentiation}

\section{Stem cell-derived extracellular vesicles regulate Th1/Th2 balance}

On the one hand, SC-EVs have been reported to induce the immune response of $\mathrm{T}$ helper type 1 (Th1) conversion to $\mathrm{T}$ helper type 2 (Th2). For example, SC-EVs drove the shift from Th1 toward Th2 cells and reestablished Th1/Th2 homeostasis by downregulating pro-inflammatory TNF- $\alpha$ and INF- $\gamma$ and upregulating anti-inflammatory IL-10 or IL-4 $(29,44,51,74,76)$ (Table 1). Moreover, SC-EVs could also regulate Th2 immune response toward Th1. For example, in the early stage of allergic asthma, the immune response mediated by Th2 cells was primarily through eosinophilic infiltration (49). Human ADMSC-EVs were observed to downregulate eosinophil infiltration and IL-4, IL-5, and TGF- $\beta$ levels, whereas they did not affect IFN- $\gamma$ and IL-10 in the bronchoalveolar lavage fluid (BALF) (49). The advanced acute severe refractory asthma is a mixed immune response by $\mathrm{Th} 2 / \mathrm{Th} 17$, and an allergic airway inflammation mediated by neutrophils and eosinophils. Human BM-MSCEVs were observed to inhibit the infiltration of neutrophils and eosinophils and downregulate IL-4, IL-5, and IL-17 expression while upregulating IFN- $\gamma$ and IL-10 expression in BALF (75). The possible mechanism is that SC-EVs shift the inflammatory responses from Th2 or Th2/Th17 toward upregulation of counter-regulatory Th1 response and/or secretion of antiinflammatory mediators, such as IL-10 $(49,75)$ (Table 1). Based on the immune balance effect exerted by SC-EVs on Th1/Th2 cells, these studies provide the basis for preclinical trials of Th1/Th2 immune response disorders.

\section{Stem cell-derived extracellular vesicles regulate Th17/Treg balance}

SC-EVs regulate Th17/Treg balance such as inhibition the differentiation of activated CD4+ $\mathrm{T}$ cells into Th17 cells, downregulation pro-inflammatory IL-17, promotion differentiation of Tregs $(31,51,74,76,94)$ (Table 1 ) and CTLA$4+$ Tregs (74), upregulation anti-inflammatory TGF- $\beta$, and inhibition aberrant inflammatory responses in stroke (31), type 1 diabetes $(51,76)$, and chronic periodontitis (94). A possible underlying mechanism could be the immune equilibrium controlled by PGE2 and TGF- $\beta$ (76) signaling pathways or miRNA-155-5p (94) in EVs. A second underlying mechanism could be the induction of phenotypic transition of macrophages into $\mathrm{M} 2$ to regulate $\mathrm{T}$ cells indirectly by EVs derived from human NSCs (31) (Table 1). Considered in conjunction, SCEVs alleviate the inflammatory microenvironment through Th17/Treg regulatory network. PGE2 protein, TGF- $\beta$ protein, and miR-155-5p may act as promising therapeutic targets against immune imbalance.

\section{Stem cell-derived extracellular vesicles inhibit naive T cell differentiation into Th1, Th2, Th17, Tfh, and Tc1 cells and upregulate Tregs}

In type 1 diabetes, SC-EVs were reported to downregulate IFN$\gamma$ and IL-17 (77, 97), upregulate IL-10 and TGF- $\beta$ (77), inhibit activated $\mathrm{T}$ cell differentiation into Th1 and Th17 cells $(77,97)$ 
(Table 1), and increase Treg expression (77), thereby inducing immunotolerance. Additionally, in the Sjögren syndrome disease model, SC-EVs were observed to prevent disease progression by repressing differentiation of naive $\mathrm{CD} 4+\mathrm{T}$ cell into $\mathrm{T}$ follicular helper (Tfh) and Th17 cells (99) (Table 1). In a contact hypersensitivity (CHS) mouse model, hUC-MSC-EVs were observed to inhibit CD8+IFN- $\gamma+$ cytotoxic T (Tc1) cells and Th1 cell immune responses and to induce Treg expression (45). One underlying mechanism could be that SC-EVs inhibit $\mathrm{T}$ cell differentiation into Th1 cells (98) or Th2 cells (52) (Table 1) while promoting Treg differentiation (91) (Table 1) by inducing phenotypic transformation of APCs (52, 77, 91, 97-99). Another underlying mechanism could be that SCEVs regulate the expression of the related genes involved in inflammation and immune cell development; for example, they could upregulate miR-let-7b and miR-let-7d and downregulate miR-155 in Treg cells (119). Additionally, the study on MSC transplantation (MSCT) in tight-skin mice model demonstrated that BM-MSCs in recipients could take up and reuse miR-151$5 p$ loaded in the MSC-EVs of donors to inhibit IL4R $\alpha / m T O R$ pathway, downregulate IL-4, inhibit Th2 cell differentiation and infiltration, and contribute to the rebuilding of BM-MSC function and BM homeostasis (78) (Table 1). These findings delineate EV-mediated immune responses for cross talk between SC-T cell subsets that provide potential therapeutic targets for autoimmune diseases.

\section{Stem Cell-Derived Extracellular Vesicle Potential in T Cell Apoptosis}

While SC-EVs were observed to exert no effect on $\mathrm{T}$ cell proliferation, they induce $\mathrm{T}$ cell apoptosis $(74,79,109)$, possibly through an SC-EV-mediated mechanism via adenosine A2A receptor (79) (Table 1). For example, in a study on human-intomouse xenogeneic chronic and severe GVHD model, a significant increase was observed in pathogenic $\mathrm{CD} 39+\mathrm{Th} 1$ cell population. Human BM-MSC-derived CD73+ exosomes were observed to function synergistically with CD39-expressing Th1 cells to accelerate massive accumulation of adenosine signals, resulting in specific apoptosis of adenosine A2A receptor-expressing Th1 cells, thereby downregulating IFN- $\gamma$ and TNF- $\alpha$. This resulted in the attenuation of inflammatory response in vivo (79) (Table 1). Collectively, the findings propose a significant EV-mediated cross talk between SCs and T cells by purinergenic signaling, which sheds light on the potential of EV-based therapeutic approach against immunological diseases.

\section{Stem Cell-Derived Extracellular Vesicle Potential in T Cell Migration and Infiltration}

Despite the limited effect exerted on the proliferation and activation of autologous $\mathrm{T}$ cells, SC-EVs have been shown to inhibit the infiltration of $\mathrm{T}$ cells in lesions $(42,54)$, thus attenuating inflammatory injury. This could be attributed to the downregulation of C-C motif chemokine ligand-21 (CCL-21, capable of attracting $\mathrm{T}$ cells) expression mediated by human UCMSC exosomes (42) (Table 1). This could also be attributed to the inhibitory effect exerted by AD-SC-EVs on the adhesion and trafficking of pathogenic $\mathrm{T}$ cells in spinal cord pial venules in early stages of the disease through interference with the integrindependent chemokine-induced signal transduction pathways without affecting adhesive molecule expression (54) (Table 1).

\section{B Cells}

\section{The Diverse Immunoregulatory Effects of Stem} Cell-Derived Extracellular Vesicles on B Cells

In a co-culture of activated PBMCs and MSC-EVs, preferential uptake of EVs by B cells exerted a stronger inhibitory effect on the proliferation of B cells than on other immune cells (30). In a similar experiment, MSC-EVs were internalized only by activated CD19+/CD86+ B cells to inhibit proliferation, differentiation, and antibody production of B cells and to hinder memory $\mathrm{B}$ cell maturation (120). However, under normal or hypoxic conditions, human amniotic fluid SC-derived EVs (AFSC-EVs) exerted limited inhibitory effect on proliferation of activated PBMCs, whereas they exerted significant immunoregulatory effects by inhibiting maturation of CD27+CD19+ memory B cells (121).

\section{Stem Cell-Derived Extracellular Vesicle Potential in B Cell/Plasma Cell Proliferation and Activation}

SC-EVs were observed to suppress B cell proliferation (30, 80, $81,108,120)$, activation $(81,83)$ and migration (81) in order to induce anti-inflammatory immune responses. In vitro, SCEVs have been observed to exert immunosuppressive effects by mediating differential mRNA expression of relevant genes in activated B cells (80) (Table 1) or by downregulating PI3K-AKT signaling pathway and inhibiting actin activation in B cells via the delivery of miR-155-5p (81) (Table 1). Additionally, SC-EVs could also interact with tumor B cells [in chronic lymphocytic leukemia (CLL)]. For instance, BM-MSC-EVs were reported to induce CLL B cell gene expression profile modification, promote CLL B cell survival and their migration, and rescue them from apoptosis (82) (Table 1). The promotive effect of SC-EVs on CCL $\mathrm{B}$ cells serves as a basis for the exploration of a therapeutic target for hematological diseases. The study (82) that mechanistically links CLL B cells and SC-EVs with disease progression has provided a pathophysiologically relevant context or the acquired immunomodulatory activity of SCs.

\section{Stem Cell-Derived Extracellular Vesicle Potentials in B Cell/Plasma Cell Differentiation}

SC-EVs were observed to inhibit B cell/plasma cell (PC) differentiation and antibody production $(29,80,83,108)$ and to induce production of IL-10-expressing regulatory B cells (Bregs) $(29,83)$, thus inducing anti-inflammatory immune response. These findings are suggestive of the ability of SCs to suppress B cell inflammation. In addition, human primary BM-MSCs mediate in vitro differentiation and maturation of circulating antibody-secreting cells (ASCs) to BM long-lived PCs (LLPCs), possibly through MSC-EVs (84), thereby promoting the survival of ASC or PCs in peripheral blood collected from healthy subjects and facilitating $\operatorname{IgG}$ secretion $(3,84)$ (Table 1). This might be attributed to the utilization of EVmediated delivery of signaling proteins (fibronectin-1, YWHAZ), a proliferation-inducing ligand (APRIL), and hypoxic conditions in the peripheral environment by post-irradiated MSC to 
facilitate LLPC survival by downregulation of mTORC1 signaling and upregulation of hypoxia signatures (84). Understanding the mechanisms of human PC differentiation and maintenance will facilitate in vitro culture of antibodies in the near future.

\section{CONCLUDING REMARKS AND FUTURE PERSPECTIVES}

As discussed in this review, the immunoregulatory potential of SC-EVs against immune cells is dependent on cell type, cellular status, the maturity of origin cells, and the type of EVs, among other factors. However, in multiple studies, SCEVs were reported to inhibit immune cell production and promote an immunotolerant microenvironment. The immune responses regulated by $\mathrm{SC}-\mathrm{EV}$ s are comparable with those mediated by stem/progenitor cells. Treatment using EVs has multiple advantages over cell therapy, like their small size, which prevents entrapment in filter organs like the lungs, liver, and spleen. Moreover, the membrane-binding property of EVs imparts exceptional biocompatibility and biostability to the encapsulated cargos. As a promising candidate for novel cellfree therapy, EVs may be widely used as an alternative to SCs in management of a variety of immunity-related diseases for maintenance of the microenvironment for tissue homeostasis and tissue regeneration upon injury. However, there are multiple questions that remain unanswered. For example, how do SC-EVs

\section{REFERENCES}

1. Shao H, Im H, Castro CM, Breakefield X, Weissleder R, Lee H. New technologies for analysis of extracellular vesicles. Chem Rev. (2018) 118:1917-50. doi: 10.1021/acs.chemrev.7b00534

2. Colombo M, Raposo G, Thery C. Biogenesis, secretion, and intercellular interactions of exosomes and other extracellular vesicles. Annu Rev Cell Dev Biol. (2014) 30:255-89. doi: 10.1146/annurev-cellbio-101512-1 22326

3. Nguyen DC, Lewis HC, Joyner C, Warren V, Xiao H, Kissick HT, et al. Extracellular vesicles from bone marrow-derived mesenchymal stromal cells support ex vivo survival of human antibody secreting cells. J Extracell Vesicles. (2018) 7:1463778. doi: 10.1080/20013078.2018.1463778

4. Phinney DG, Di Giuseppe M, Njah J, Sala E, Shiva S, St Croix CM, et al. Mesenchymal stem cells use extracellular vesicles to outsource mitophagy and shuttle microRNAs. Nat Commun. (2015) 6:8472. doi: $10.1038 /$ ncomms 9472

5. Zhou J, Ghoroghi S, Benito-Martin A, Wu H, Unachukwu UJ, Einbond LS, et al. Characterization of induced pluripotent stem cell microvesicle genesis, morphology and pluripotent content. Sci Rep. (2016) 6:19743. doi: 10.1038/srep19743

6. Tang XD, Shi L, Monsel A, Li XY, Zhu HL, et al. Mesenchymal stem cell microvesicles attenuate acute lung injury in mice partly mediated by ang-1 mRNA. Stem Cells. (2017) 35:1849-59. doi: 10.1002/stem.2619

7. Lee WH, Chen WY, Shao NY, Xiao D, Qin X, Baker N, et al. Comparison of non-coding RNAs in exosomes and functional efficacy of human embryonic stem cell- versus induced pluripotent stem cell-derived cardiomyocytes. Stem Cells. (2017) 35:2138-49. doi: 10.1002/stem.2669

8. Morrison TJ, Jackson MV, Cunningham EK, Kissenpfennig A, McAuley DF, O'Kane CM, et al. Mesenchymal stromal cells modulate macrophages in clinically relevant lung injury models by extracellular vesicle mitochondrial transfer. Am J Respir Crit Care Med. (2017) 196:1275-86. doi: 10.1164/rccm.201701-0170OC home damaged tissues? Or how do SC-EV-transferred specific miRNAs target the genes in recipient cells? So far, different animal models have been used in multiple studies to investigate the immunoregulatory roles of stem/progenitor cell-derived EVs; yet limited clinical studies have been conducted on application of SC-EVs to human subjects (122). Therefore, an extensive body of research is necessary before we adopt large-scale application of SC-EVs in clinical practice.

\section{AUTHOR CONTRIBUTIONS}

MX and ZS prepared the table and figure. MX, WX, ZW, $\mathrm{AA}, \mathrm{WW}$, and CW drafted the manuscript. MX, WX, and CW edited and revised the manuscript. All authors contributed to manuscript revision and read and approved the submitted version.

\section{FUNDING}

This work was supported by grants from the Natural Science Foundation of Hunan Province in China (grant no. 2019JJ40413).

\section{ACKNOWLEDGMENTS}

The authors thanked Junying Tian for reviewing and editing this paper.
9. Jeppesen DK, Fenix AM, Franklin JL, Higginbotham JN, Zhang Q, Zimmerman LJ, et al. Reassessment of exosome composition. Cell. (2019) 177:428-445.e18. doi: 10.1016/j.cell.2019.02.029

10. Alvarez V, Sanchez-Margallo FM, Macias-Garcia B, Gomez-Serrano M, Jorge I, Vazquez J, et al. The immunomodulatory activity of extracellular vesicles derived from endometrial mesenchymal stem cells on $\mathrm{CD} 4+\mathrm{T}$ cells is partially mediated by TGFbeta. J Tissue Eng Regen Med. (2018) 12:2088-98. doi: $10.1002 /$ term. 2743

11. Kerkela E, Laitinen A, Rabina J, Valkonen S, Takatalo M, Larjo A, et al. Adenosinergic immunosuppression by human mesenchymal stromal cells requires co-Operation with T cells. Stem Cells. (2016) 34:781-90. doi: $10.1002 /$ stem. 2280

12. Fafian-Labora J, Lesende-Rodriguez I, Fernandez-Pernas P, SangiaoAlvarellos S, Monserrat L, Arntz OJ, et al. Effect of age on proinflammatory miRNAs contained in mesenchymal stem cell-derived extracellular vesicles. Sci Rep. (2017) 7:43923. doi: 10.1038/srep 43923

13. Kishore R, Khan M. More than tiny sacks: stem cell exosomes as cell-free modality for cardiac repair. Circ Res. (2016) 118:330-43. doi: 10.1161/circresaha.115.307654

14. Cossetti C, Iraci N, Mercer TR, Leonardi T, Alpi E, Drago D, et al. Extracellular vesicles from neural stem cells transfer IFN-gamma via Ifngr1 to activate Stat1 signaling in target cells. Mol Cell. (2014) 56:193-204. doi: 10.1016/j.molcel.2014.08.020

15. Zhou J, Benito-Martin A, Mighty J, Chang L, Ghoroghi S, Wu H, et al. Retinal progenitor cells release extracellular vesicles containing developmental transcription factors, microRNA and membrane proteins. Sci Rep. (2018) 8:2823. doi: $10.1038 / \mathrm{s} 41598-018-20421-1$

16. Burrello J, Monticone S, Gai C, Gomez Y, Kholia S, Camussi G. Stem cellderived extracellular vesicles and immune-modulation. Front Cell Dev Biol. (2016) 4:83. doi: 10.3389/fcell.2016.00083

17. Chi KR. The tumour trail left in blood. Nature. (2016) 532:269-71. doi: $10.1038 / 532269 a$ 
18. Casado S, Lobo M, Paino CL. Dynamics of plasma membrane surface related to the release of extracellular vesicles by mesenchymal stem cells in culture. Sci Rep. (2017) 7:6767. doi: 10.1038/s41598-017-07265-x

19. Riazifar M, Pone EJ, Lotvall J, Zhao W. Stem cell extracellular vesicles: extended messages of regeneration. Annu Rev Pharmacol Toxicol. (2017) 57:125-54. doi: 10.1146/annurev-pharmtox-061616-030146

20. Ravichandran KS. Find-me and eat-me signals in apoptotic cell clearance: progress and conundrums. J Exp Med. (2010) 207:1807-17. doi: 10.1084/jem.20101157

21. Poon IKH, Gregory CD, Kaparakis-Liaskos M. Editorial: the immunomodulatory properties of extracellular vesicles from pathogens, immune cells, and non-immune cells. Front Immunol. (2018) 9:3024. doi: 10.3389/fimmu.2018.03024

22. Gouveia de Andrade AV, Bertolino G, Riewaldt J, Bieback K, Karbanova J, Odendahl M, et al. Extracellular vesicles secreted by bone marrow- and adipose tissue-derived mesenchymal stromal cells fail to suppress lymphocyte proliferation. Stem Cells Dev. (2015) 24:1374-76. doi: 10.1089/scd.2014.0563

23. Jackson MV, Morrison TJ, Doherty DF, McAuley DF, Matthay MA, Kissenpfennig A, et al. Mitochondrial transfer via tunneling nanotubes is an important mechanism by which mesenchymal stem cells enhance macrophage phagocytosis in the in vitro and in vivo models of ARDS. Stem Cells. (2016) 34:2210-23. doi: 10.1002/stem. 2372

24. Mulcahy LA, Pink RC, Carter DR. Routes and mechanisms of extracellular vesicle uptake. J Extracell Vesicles. (2014) 3:24641. doi: 10.3402/jev.v3.24641

25. Raposo G, Stoorvogel W. Extracellular vesicles: exosomes, microvesicles, and friends. J Cell Biol. (2013) 200:373-83. doi: 10.1083/jcb.201211138

26. Shen B, Liu J, Zhang F, Wang Y, Qin Y, Zhou Z, et al. CCR2 positive exosome released by mesenchymal stem cells suppresses macrophage functions and alleviates ischemia/reperfusion-induced renal injury. Stem Cells Int. (2016) 2016:1240301. doi: 10.1155/2016/1240301

27. Henao Agudelo JS, Braga TT, Amano MT, Cenedeze MA, Cavinato RA, Peixoto-Santos AR, et al. Mesenchymal stromal cell-derived microvesicles regulate an internal pro-inflammatory program in activated macrophages. Front Immunol. (2017) 8:881. doi: 10.3389/fimmu.2017.00881

28. Zou X, Zhang G, Cheng Z, Yin D, Du T, Ju G, et al. Microvesicles derived from human Wharton's Jelly mesenchymal stromal cells ameliorate renal ischemia-reperfusion injury in rats by suppressing CX3CL1. Stem Cell Res Ther. (2014) 5:40. doi: 10.1186/scrt428

29. Cosenza S, Toupet K, Maumus M, Luz-Crawford P, Blanc-Brude O, Jorgensen C, et al. Mesenchymal stem cells-derived exosomes are more immunosuppressive than microparticles in inflammatory arthritis. Theranostics. (2018) 8:1399-410. doi: 10.7150/thno.21072

30. Di Trapani M, Bassi G, Midolo M, Gatti A, Kamga PT, Cassaro A, et al. Differential and transferable modulatory effects of mesenchymal stromal cell-derived extracellular vesicles on T, B and NK cell functions. Sci Rep. (2016) 6:24120. doi: 10.1038/srep24120

31. Webb RL, Kaiser EE, Scoville SL, Thompson TA, Fatima S, Pandya C, et al. Human neural stem cell extracellular vesicles improve tissue and functional fecovery in the murine thromboembolic stroke model. Transl Stroke Res. (2018) 9:530-39. doi: 10.1007/s12975-017-0599-2

32. Silva AM, Almeida MI, Teixeira JH, Maia AF, Calin GA, Barbosa MA, et al. Dendritic cell-derived extracellular vesicles mediate mesenchymal stem/stromal cell recruitment. Sci Rep. (2017) 7:1667. doi: 10.1038/s41598-017-01809-x

33. Seo N, Shirakura Y, Tahara Y, Momose F, Harada N, Ikeda H, et al. Activated CD8(+) T cell extracellular vesicles prevent tumour progression by targeting of lesional mesenchymal cells. Nat Commun. (2018) 9:435. doi: 10.1038/s41467-018-02865-1

34. Gabrusiewicz K, Li X, Wei J, Hashimoto Y, Marisetty AL, Ott M, et al. Glioblastoma stem cell-derived exosomes induce M2 macrophages and PDL1 expression on human monocytes. Oncoimmunology. (2018) 7:e1412909. doi: 10.1080/2162402x.2017.1412909

35. Zou X, Gu D, Zhang G, Zhong L, Cheng Z, Liu G, et al. NK cell regulatory property is involved in the protective role of MSC-derived extracellular vesicles in renal ischemic reperfusion injury. Hum Gene Ther. (2016) 27:92635. doi: 10.1089/hum.2016.057
36. Li X, Liu L, Yang J, Yu Y, Chai J, Wang L, et al. Exosome derived from human umbilical cord mesenchymal stem cell mediates MiR-181c attenuating burn-induced excessive inflammation. EBioMedicine. (2016) 8:72-82. doi: 10.1016/j.ebiom.2016.04.030

37. Jiang L, Zhang S, Hu H, Yang J, Wang X, Ma Y, et al. Exosomes derived from human umbilical cord mesenchymal stem cells alleviate acute liver failure by reducing the activity of the NLRP3 inflammasome in macrophages. Biochem Biophys Res Commun. (2019) 508:735-41. doi: 10.1016/j.bbrc.2018.11.189

38. Spinosa M, Lu G, Su G, Bontha SV, Gehrau R, Salmon MD, et al. Human mesenchymal stromal cell-derived extracellular vesicles attenuate aortic aneurysm formation and macrophage activation via microRNA-147. FASEB J. (2018) 29:fj201701138RR. doi: 10.1096/fj.201701138RR

39. Ti D, Hao H, Tong C, Liu J, Dong L, Zheng J, et al. LPS-preconditioned mesenchymal stromal cells modify macrophage polarization for resolution of chronic inflammation via exosome-shuttled let-7b. J Transl Med. (2015) 13:308. doi: 10.1186/s12967-015-0642-6

40. Song Y, Dou H, Li X, Zhao X, Li Y, Liu D, et al. Exosomal miR-146a contributes to the enhanced therapeutic efficacy of interleukin-1beta-primed mesenchymal stem cells against sepsis. Stem Cells. (2017) 35:1208-21. doi: $10.1002 /$ stem. 2564

41. Yu B, Shao H, Su C, Jiang Y, Chen X, Bai L, et al. Exosomes derived from MSCs ameliorate retinal laser injury partially by inhibition of MCP-1. Sci Rep. (2016) 6:34562. doi: 10.1038/srep34562

42. Bai L, Shao H, Wang H, Zhang Z, Su C, Dong L, et al. Effects of mesenchymal stem cell-derived exosomes on experimental autoimmune uveitis. Sci Rep. (2017) 7:4323. doi: 10.1038/s41598-017-04559-y

43. Shao L, Zhang Y, Pan X, Liu B, Liang C, Zhang Y, et al. Knockout of beta-2 microglobulin enhances cardiac repair by modulating exosome imprinting and inhibiting stem cell-induced immune rejection. Cell Mol Life Sci. (2019). doi: 10.1007/s00018-019-03220-3. [Epub ahead of print].

44. Wang L, Gu Z, Zhao X, Yang N, Wang F, Deng A, et al. Extracellular vesicles released from human umbilical cord-derived mesenchymal stromal cells prevent life-threatening acute graft-versus-host disease in a mouse model of allogeneic hematopoietic stem cell transplantation. Stem Cells Dev. (2016) 25:1874-83. doi: $10.1089 / \mathrm{scd} .2016 .0107$

45. Guo L, Lai P, Wang Y, Huang T, Chen X, Luo C, et al. Extracellular vesicles from mesenchymal stem cells prevent contact hypersensitivity through the suppression of Tc1 and Th1 cells and expansion of regulatory T cells. Int Immunopharmacol. (2019) 74:105663. doi: 10.1016/j.intimp.2019.05.048

46. Thomi G, Surbek D, Haesler V, Joerger-Messerli M, Schoeberlein A. Exosomes derived from umbilical cord mesenchymal stem cells reduce microglia-mediated neuroinflammation in perinatal brain injury. Stem Cell Res Ther. (2019) 10:105. doi: 10.1186/s13287-019-1207-z

47. Lo Sicco C, Reverberi D, Balbi C, Ulivi V, Principi E, Pascucci L, et al. Mesenchymal stem cell-derived extracellular vesicles as mediators of antiinflammatory effects: endorsement of macrophage polarization. Stem Cells Transl Med. (2017) 6:1018-28. doi: 10.1002/sctm.16-0363

48. Goncalves FD, Luk F, Korevaar SS, Bouzid R, Paz AH, Lopez-Iglesias C, et al. Membrane particles generated from mesenchymal stromal cells modulate immune responses by selective targeting of pro-inflammatory monocytes. Sci Rep. (2017) 7:12100. doi: 10.1038/s41598-017-12121-z

49. de Castro LL, Xisto DG, Kitoko JZ, Cruz FF, Olsen PC, Redondo PA, et al. Human adipose tissue mesenchymal stromal cells and their extracellular vesicles act differentially on lung mechanics and inflammation in experimental allergic asthma. Stem Cell Res Ther. (2017) 8:151. doi: 10.1186/s13287-017-0600-8

50. Liu Y, Lou G, Li A, Zhang T, Qi J, Ye D, et al. AMSC-derived exosomes alleviate lipopolysaccharide/d-galactosamine-induced acute liver failure by miR-17-mediated reduction of TXNIP/NLRP3 inflammasome activation in macrophages. EBioMedicine. (2018) 36:140-50. doi: 10.1016/j.ebiom.2018.08.054

51. Nojehdehi S, Soudi S, Hesampour A, Rasouli S, Soleimani M, Hashemi SM. Immunomodulatory effects of mesenchymal stem cell-derived exosomes on experimental type-1 autoimmune diabetes. J Cell Biochem. (2018) 119:943343. doi: $10.1002 /$ jcb. 27260

52. Cho KS, Kang SA, Kim SD, Mun SJ, Yu HS, Roh HJ. Dendritic cells and M2 macrophage play an important role in suppression of Th2-mediated 
inflammation by adipose stem cells-derived extracellular vesicles. Stem Cell Res. (2019) 39:101500. doi: 10.1016/j.scr.2019.101500

53. Zhao H, Shang Q, Pan Z, Bai Y, Li Z, Zhang H, et al. Exosomes from adiposederived stem cells attenuate adipose inflammation and obesity through polarizing M2 macrophages and beiging in white adipose tissue. Diabetes. (2018) 67:235-47. doi: 10.2337/db17-0356

54. Farinazzo A, Angiari S, Turano E, Bistaffa E, Dusi S, Ruggieri S, et al. Nanovesicles from adipose-derived mesenchymal stem cells inhibit $\mathrm{T}$ lymphocyte trafficking and ameliorate chronic experimental autoimmune encephalomyelitis. Sci Rep. (2018) 8:7473. doi: 10.1038/s41598-018-25676-2

55. Deng S, Zhou X, Ge Z, Song Y, Wang H, Liu X, et al. Exosomes from adipose-derived mesenchymal stem cells ameliorate cardiac damage after myocardial infarction by activating S1P/SK1/S1PR1 signaling and promoting macrophage M2 polarization. Int J Biochem Cell Biol. (2019) 114:105564. doi: 10.1016/j.biocel.2019.105564

56. Ko SF, Yip HK, Zhen YY, Lee CC, Lee CC, Huang CC, et al. Adiposederived mesenchymal stem cell exosomes suppress hepatocellular carcinoma growth in a rat model: apparent diffusion coefficient, natural killer T-cell responses, and histopathological features. Stem Cells Int. (2015) 2015:853506. doi: 10.1155/2015/853506

57. Feng N, Jia Y, Huang X. Exosomes from adipose-derived stem cells alleviate neural injury caused by microglia activation via suppressing NF-kB and MAPK pathway. J Neuroimmunol. (2019) 334:576996. doi: 10.1016/j.jneuroim.2019.576996

58. Geng W, Tang H, Luo S, Lv Y, Liang D, Kang X, et al. Exosomes from miRNA126-modified ADSCs promotes functional recovery after stroke in rats by improving neurogenesis and suppressing microglia activation. Am J Ttransl Res. (2019) 11:780-92.

59. Jiang $M$, Wang $H$, Jin $M$, Yang $X$, Ji H, Jiang $Y$, et al. Exosomes from miR-30d-5p-ADSCs reverse acute ischemic stroke-induced, autophagymediated brain injury by promoting M2 microglial/macrophage polarization. Cell Physiol Biochem. (2018) 47:864-78. doi: 10.1159/0004 90078

60. Wu XQ, Yan TZ, Wang ZW, Wu X, Cao GH, Zhang C. BM-MSCs-derived microvesicles promote allogeneic kidney graft survival through enhancing micro-146a expression of dendritic cells. Immunol Lett. (2017) 191:55-62. doi: 10.1016/j.imlet.2017.09.010

61. He JG, Xie QL, Li BB, Zhou L, Yan D. Exosomes derived from IDO1-overexpressing rat bone marrow mesenchymal stem cells promote immunotolerance of cardiac allografts. Cell Transplant. 2018:963689718805375. doi: 10.1177/0963689718805375

62. Reis M, Mavin E, Nicholson L, Green K, Dickinson AM, Wang XN. Mesenchymal stromal cell-derived extracellular vesicles attenuate dendritic cell maturation and function. Front Immunol. (2018) 9:2538. doi: 10.3389/fimmu.2018.02538

63. Li J, Xue H, Li T, Chu X, Xin D, Xiong Y, et al. Exosomes derived from mesenchymal stem cells attenuate the progression of atherosclerosis in $\operatorname{ApoE}(-/-)$ mice via miR-let7 mediated infiltration and polarization of M2 macrophage. Biochem Biophys Res Commun. (2019) 510:565-72. doi: 10.1016/j.bbrc.2019.02.005

64. Wang X, Gu H, Qin D, Yang L, Huang W, Essandoh K, et al. Exosomal miR-223 contributes to mesenchymal stem cell-elicited cardioprotection in polymicrobial sepsis. Sci Rep. (2015) 5:13721. doi: 10.1038/srep13721

65. Xu R, Zhang F, Chai R, Zhou W, Hu M, Liu B, et al. Exosomes derived from pro-inflammatory bone marrow-derived mesenchymal stem cells reduce inflammation and myocardial injury via mediating macrophage polarization. J Cell Mol Med. (2019) 23:7617-31. doi: 10.1111/jcmm.14635

66. Ren W, Hou J, Yang C, Wang H, Wu S, Wu Y, et al. Extracellular vesicles secreted by hypoxia pre-challenged mesenchymal stem cells promote nonsmall cell lung cancer cell growth and mobility as well as macrophage M2 polarization via miR-21-5p delivery. J Exp Clin Cancer Res. (2019) 38:62. doi: 10.1186/s13046-019-1027-0

67. Sun X, Shan A, Wei Z, Xu B. Intravenous mesenchymal stem cellderived exosomes ameliorate myocardial inflammation in the dilated cardiomyopathy. Biochem Biophys Res Commun. (2018) 503:2611-8. doi: 10.1016/j.bbrc.2018.08.012

68. Zhao J, Li X, Hu J, Chen F, Qiao S, Sun X, et al. Mesenchymal stromal cell-derived exosomes attenuate myocardial ischemia-reperfusion injury through miR-182-regulated macrophage polarization. Cardiovasc Res. (2019) 115:1205-16. doi: 10.1093/cvr/cvz040

69. Cao L, Xu H, Wang G, Liu M, Tian D, Yuan Z. Extracellular vesicles derived from bone marrow mesenchymal stem cells attenuate dextran sodium sulfate-induced ulcerative colitis by promoting M2 macrophage polarization. Int Immunopharmacol. (2019) 72:264-74. doi: 10.1016/j.intimp.2019.04.020

70. He X, Dong Z, Cao Y, Wang H, Liu S, Liao L, et al. MSC-derived exosome promotes M2 polarization and enhances cutaneous wound healing. Stem Cells Int. (2019) 2019:7132708. doi: 10.1155/2019/7132708

71. Fujii S, Miura Y, Fujishiro A, Shindo T, Shimazu Y, Hirai H, et al. Graftversus-host disease amelioration by human bone marrow mesenchymal stromal/stem cell-derived extracellular vesicles is associated with peripheral preservation of naive T cell populations. Stem Cells. (2018) 36:434-45. doi: $10.1002 /$ stem. 2759

72. Hu B, Chen S, Zou M, He Z, Shao S, Liu B. Effect of extracellular vesicles on neural functional recovery and immunologic suppression after rat cerebral apoplexy. Cell Physiol Biochem. (2016) 40:155-62. doi: 10.1159/000452533

73. Doeppner TR, Herz J, Gorgens A, Schlechter J, Ludwig AK, Radtke S, et al. Extracellular vesicles improve post-stroke neuroregeneration and prevent postischemic immunosuppression. Stem Cells Transl Med. (2015) 4:1131-43. doi: 10.5966/sctm.2015-0078

74. Chen W, Huang Y, Han J, Yu L, Li Y, Lu Z, et al. Immunomodulatory effects of mesenchymal stromal cells-derived exosome. Immunol Res. (2016) 64:831-40. doi: 10.1007/s12026-016-8798-6

75. Cruz FF, Borg ZD, Goodwin M, Sokocevic D, Wagner DE, Coffey A, et al. Systemic administration of human bone marrow-derived mesenchymal stromal cell extracellular vesicles ameliorates aspergillus hyphal extractinduced allergic airway inflammation in immunocompetent mice. Stem Cells Transl Med. (2015) 4:1302-16. doi: 10.5966/sctm.2014-0280

76. Favaro E, Carpanetto A, Lamorte S, Fusco A, Caorsi C, Deregibus MC, et al. Human mesenchymal stem cell-derived microvesicles modulate $\mathrm{T}$ cell response to islet antigen glutamic acid decarboxylase in patients with type 1 diabetes. Diabetologia. (2014) 57:1664-73. doi: 10.1007/s00125-014-3262-4

77. Favaro E, Carpanetto A, Caorsi C, Giovarelli M, Angelini C, Cavallo-Perin $\mathrm{P}$, et al. Human mesenchymal stem cells and derived extracellular vesicles induce regulatory dendritic cells in type 1 diabetic patients. Diabetologia. (2016) 59:325-33. doi: 10.1007/s00125-015-3808-0

78. Chen C, Wang D, Moshaverinia A, Liu D, Kou X, Yu W, et al. Mesenchymal stem cell transplantation in tight-skin mice identifies miR-151-5p as a therapeutic target for systemic sclerosis. Cell Res. (2017) 27:559-77. doi: $10.1038 / \mathrm{cr} .2017 .11$

79. Amarnath S, Foley JE, Farthing DE, Gress RE, Laurence A, Eckhaus MA, et al. Bone marrow-derived mesenchymal stromal cells harness purinergenic signaling to tolerize human Th1 cells in vivo. Stem Cells. (2015) 33:1200-12. doi: $10.1002 /$ stem. 1934

80. Khare D, Or R, Resnick I, Barkatz C, Almogi-Hazan O, Avni B. Mesenchymal stromal cell-derived exosomes affect mRNA expression and function of B-lymphocytes. Front Immunol. (2018) 9:3053. doi: 10.3389/fimmu.2018. 03053

81. Adamo A, Brandi J, Caligola S, Delfino P, Bazzoni R, Carusone R, et al. Extracellular vesicles mediate mesenchymal stromal cell-dependent regulation of B cell PI3K-AKT signaling pathway and actin cytoskeleton. Front Immunol. (2019) 10:446. doi: 10.3389/fimmu.2019.00446

82. Crompot E, Van Damme M, Pieters K, Vermeersch M, Perez-Morga D, Mineur P, et al. Extracellular vesicles of bone marrow stromal cells rescue chronic lymphocytic leukemia B cells from apoptosis, enhance their migration and induce gene expression modifications. Haematologica. (2017) 102:1594-604. doi: 10.3324/haematol.2016.163337

83. Cosenza S, Ruiz M, Toupet K, Jorgensen C, Noel D. Mesenchymal stem cells derived exosomes and microparticles protect cartilage and bone from degradation in osteoarthritis. Sci Rep. (2017) 7:16214. doi: 10.1038/s41598-017-15376-8

84. Nguyen DC, Garimalla S, Xiao H, Kyu S, Albizua I, Galipeau J, et al. Factors of the bone marrow microniche that support human plasma cell survival and immunoglobulin secretion. Nat Commun. (2018) 9:3698. doi: 10.1038/s41467-018-05853-7

85. Jaimes Y, Naaldijk Y, Wenk K, Leovsky C, Emmrich F. Mesenchymal stem cell-derived microvesicles modulate lipopolysaccharides-induced 
inflammatory responses to microglia cells. Stem Cells. (2017) 35:812-23. doi: 10.1002/stem.2541

86. Liu W, Wang Y, Gong F, Rong Y, Luo Y, Tang P, et al. Exosomes derived from bone mesenchymal stem cells repair traumatic spinal cord injury by suppressing the activation of A1 neurotoxic reactive astrocytes. $J$ Neurotrauma. (2019) 36:469-84. doi: 10.1089/neu.2018.5835

87. Zavatti M, Beretti F, Casciaro F, Bertucci E, Maraldi T. Comparison of the therapeutic effect of amniotic fluid stem cells and their exosomes on monoiodoacetate-induced animal model of osteoarthritis. Biofactors. (2019) 46:106-17. doi: 10.1002/biof.1576

88. Romani R, Pirisinu I, Calvitti M, Pallotta MT, Gargaro M, Bistoni G, et al. Stem cells from human amniotic fluid exert immunoregulatory function via secreted indoleamine 2,3-dioxygenase1. J Cell Mol Med. (2015) 19:1593-605. doi: $10.1111 / \mathrm{jcmm} .12534$

89. Singla DK, Johnson TA, Tavakoli Dargani Z. Exosome treatment enhances anti-inflammatory M2 macrophages and reduces inflammation-induced pyroptosis in doxorubicin-induced cardiomyopathy. Cells. (2019) 8:1224. doi: $10.3390 /$ cells 8101224

90. Yaddanapudi K, Meng S, Whitt AG, Al Rayyan N, Richie J, Tu A, et al. Exosomes from GM-CSF expressing embryonic stem cells are an effective prophylactic vaccine for cancer prevention. Oncoimmunology. (2019) 8:1561119. doi: 10.1080/2162402X.2018.1561119

91. Zhang B, Yin Y, Lai RC, Tan SS, Choo AB, Lim SK. Mesenchymal stem cells secrete immunologically active exosomes. Stem Cells Dev. (2014) 23:1233-44. doi: 10.1089/scd.2013.0479

92. Crain SK, Robinson SR, Thane KE, Davis AM, Meola DM, Barton BA, et al. Extracellular vesicles from wharton's jelly mesenchymal stem cells suppress CD4 expressing T cells through transforming growth factor beta and adenosine signaling in a canine model. Stem Cells Dev. (2019) 28:212-26. doi: $10.1089 /$ scd.2018.0097

93. Kang H, Lee MJ, Park SJ, Lee MS. Lipopolysaccharide-preconditioned periodontal ligament stem cells induce M1 polarization of macrophages through extracellular vesicles. Int $J$ Mol Sci. (2018) 19:E3843. doi: $10.3390 /$ ijms 19123843

94. Zheng Y, Dong C, Yang J, Jin Y, Zheng W, Zhou Q, et al. Exosomal microRNA-155-5p from PDLSCs regulated Th17/Treg balance by targeting sirtuin-1 in chronic periodontitis. J Cell Physiol. (2019) 234:20662-74. doi: $10.1002 /$ jcp. 28671

95. Fan Y, Herr F, Vernochet A, Mennesson B, Oberlin E, Durrbach A. Human fetal liver mesenchymal stem cell-derived exosomes impair natural killer cell function. Stem Cells Dev. (2019) 28:44-55. doi: 10.1089/scd.2018.0015

96. Grange C, Tapparo M, Tritta S, Deregibus MC, Battaglia A, Gontero P, et al. Role of HLA-G and extracellular vesicles in renal cancer stem cell-induced inhibition of dendritic cell differentiation. BMC Cancer. (2015) 15:1009. doi: 10.1186/s12885-015-2025-z

97. Shigemoto-Kuroda T, Oh JY, Kim DK, Jeong HJ, Park SY, Lee HJ, et al. MSC-derived extracellular vesicles attenuate immune responses in two autoimmune murine models: type 1 diabetes and uveoretinitis. Stem Cell Reports. (2017) 8:1214-25. doi: 10.1016/j.stemcr.2017.04.008

98. Domenis R, Cesselli D, Toffoletto B, Bourkoula E, Caponnetto F, Manini I, et al. Systemic T cells immunosuppression of glioma stem cell-derived exosomes is mediated by monocytic myeloid-derived suppressor cells. PLoS ONE. (2017) 12:e0169932. doi: 10.1371/journal.pone.0169932

99. Hai B, Shigemoto-Kuroda T, Zhao Q, Lee RH, Liu F. Inhibitory effects of iPSC-MSCs and their extracellular vesicles on the onset of sialadenitis in a mouse model of sjogren's syndrome. Stem Cells Int. (2018) 2018:2092315. doi: $10.1155 / 2018 / 2092315$

100. Kordelas L, Rebmann V, Ludwig AK, Radtke S, Ruesing J, Doeppner TR, et al. MSC-derived exosomes: a novel tool to treat therapy-refractory graft-versushost disease. Leukemia. (2014) 28:970-73. doi: 10.1038/leu.2014.41

101. Thery C, Amigorena S. The cell biology of antigen presentation in dendritic cells. Curr Opin Immunol. (2001) 13:45-51. doi: 10.1016/s0952-7915(00)00180-1

102. Hyvarinen K, Holopainen M, Skirdenko V, Ruhanen H, Lehenkari P, Korhonen M, et al. Mesenchymal stromal cells and their extracellular vesicles enhance the anti-inflammatory phenotype of regulatory macrophages by downregulating the production of interleukin (IL)-23 and IL-22. Front Immunol. (2018) 9:771. doi: 10.3389/fimmu.2018.00771
103. Chu F, Shi M, Zheng C, Shen D, Zhu J, Zheng X, et al. The roles of macrophages and microglia in multiple sclerosis and experimental autoimmune encephalomyelitis. J Neuroimmunol. (2018) 318:1-7. doi: 10.1016/j.jneuroim.2018.02.015

104. Morton MC, Neckles VN, Seluzicki CM, Holmberg JC, Feliciano DM. Neonatal subventricular zone neural stem cells release extracellular vesicles that act as a microglial morphogen. Cell Rep. (2018) 23:78-89. doi: 10.1016/j.celrep.2018.03.037

105. Zhao C, Zhou X, Qiu J, Xin D, Li T, Chu X, et al. Exosomes Derived from bone marrow mesenchymal stem cells inhibit complement activation in rats with spinal cord injury. Drug Des Devel Ther. (2019) 13:3693-704. doi: 10.2147/DDDT.S209636

106. Ding M, Shen Y, Wang P, Xie Z, Xu S, Zhu Z, et al. Exosomes isolated from human umbilical cord mesenchymal stem cells alleviate neuroinflammation and reduce amyloid-beta deposition by modulating microglial activation in alzheimer's disease. Neurochem Res. (2018) 43:216577. doi: 10.1007/s11064-018-2641-5

107. Ni H, Yang S, Siaw-Debrah F, Hu J, Wu K, He Z, et al. Exosomes derived from bone mesenchymal stem cells ameliorate early inflammatory responses following traumatic brain injury. Front Neurosci. (2019) 13:14. doi: $10.3389 /$ fnins.2019.00014

108. Conforti A, Scarsella M, Starc N, Giorda E, Biagini S, Proia A, et al. Microvescicles derived from mesenchymal stromal cells are not as effective as their cellular counterpart in the ability to modulate immune responses in vitro. Stem Cells Dev. (2014) 23:2591-9. doi: 10.1089/scd.2014.0091

109. Del Fattore A, Luciano R, Pascucci L, Goffredo BM, Giorda E, Scapaticci $\mathrm{M}$, et al. Immunoregulatory effects of mesenchymal stem cell-derived extracellular vesicles on T Lymphocytes. Cell Transplant. (2015) 24:2615-27. doi: $10.3727 / 096368915 \times 687543$

110. Zhang B, Yeo RW, Lai RC, Sim EW, Chin KC, Lim SK. Mesenchymal stromal cell exosome-enhanced regulatory T-cell production through an antigen-presenting cell-mediated pathway. Cytotherapy. (2018) 20:687-96. doi: 10.1016/j.jcyt.2018.02.372

111. Du YM, Zhuansun YX, Chen R, Lin L, Lin Y, Li JG. Mesenchymal stem cell exosomes promote immunosuppression of regulatory T cells in asthma. Exp Cell Res. (2018) 363:114-20. doi: 10.1016/j.yexcr.2017.12.021

112. Blazquez R, Sanchez-Margallo FM, de la Rosa O, Dalemans W, Alvarez $\mathrm{V}$, Tarazona $\mathrm{R}$, et al. Immunomodulatory potential of human adipose mesenchymal stem cells derived exosomes on in vitro stimulated $\mathrm{T}$ cells. Front Immunol. (2014) 5:556. doi: 10.3389/fimmu.2014.00556

113. Zhang Q, Fu L, Liang Y, Guo Z, Wang L, Ma C, et al. Exosomes originating from MSCs stimulated with TGF-beta and IFN-gamma promote Treg differentiation. J Cell Physio. (2018) 233:6832-40. doi: 10.1002/jcp.26436

114. Kilpinen L, Impola U, Sankkila L, Ritamo I, Aatonen M, Kilpinen S, et al. Extracellular membrane vesicles from umbilical cord blood-derived MSC protect against ischemic acute kidney injury, a feature that is lost after inflammatory conditioning. J Extracell Vesicles. (2013) 2:21927. doi: 10.3402/jev.v2i0.21927

115. Tan SS, Yin Y, Lee T, Lai RC, Yeo RW, Zhang B, et al. Therapeutic MSC exosomes are derived from lipid raft microdomains in the plasma membrane. J Extracell Vesicles. (2013) 2:22614. doi: 10.3402/jev.v2i0.22614

116. Monguio-Tortajada M, Roura S, Galvez-Monton C, Pujal JM, Aran G, Sanjurjo L, et al. Nanosized UCMSC-derived extracellular vesicles but not conditioned medium exclusively inhibit the inflammatory response of stimulated T cells: implications for nanomedicine. Theranostics. (2017) 7:270-84. doi: 10.7150/thno.16154

117. van den Akker F, Vrijsen KR, Deddens JC, Buikema JW, Mokry M, van Laake $\mathrm{LW}$, et al. Suppression of T cells by mesenchymal and cardiac progenitor cells is partly mediated via extracellular vesicles. Heliyon. (2018) 4:e00642. doi: 10.1016/j.heliyon.2018.e00642

118. Rahman MJ, Regn D, Bashratyan R, Dai YD. Exosomes released by islet-derived mesenchymal stem cells trigger autoimmune responses in NOD mice. Diabetes. (2014) 63:1008-20. doi: 10.2337/db1 3-0859

119. Wen D, Peng Y, Liu D, Weizmann Y, Mahato RI. Mesenchymal stem cell and derived exosome as small RNA carrier and Immunomodulator to improve islet transplantation. J Control Release. (2016) 238:166-75. doi: 10.1016/j.jconrel.2016.07.044 
120. Budoni M, Fierabracci A, Luciano R, Petrini S, Di Ciommo V, Muraca M. The immunosuppressive effect of mesenchymal stromal cells on B lymphocytes is mediated by membrane vesicles. Cell Transplant. (2013) 22:369-79. doi: 10.3727/096368911x582769

121. Balbi C, Piccoli M, Barile L, Papait A, Armirotti A, Principi E, et al. First characterization of human amniotic fluid stem cell extracellular vesicles as a powerful paracrine tool endowed with regenerative potential. Stem Cells Transl Med. (2017) 6:1340-55. doi: 10.1002/sctm.16-0297

122. Borger V, Bremer M, Ferrer-Tur R, Gockeln L, Stambouli O, Becic A, et al. Mesenchymal stem/stromal cell-derived extracellular vesicles and their potential as novel immunomodulatory therapeutic agents. Int J Mol Sci. (2017) 18:E1450. doi: 10.3390/ijms18071
Conflict of Interest: The authors declare that the research was conducted in the absence of any commercial or financial relationships that could be construed as a potential conflict of interest.

Copyright (c) 2020 Xie, Xiong, She, Wen, Abdirahman, Wan and Wen. This is an open-access article distributed under the terms of the Creative Commons Attribution License (CC BY). The use, distribution or reproduction in other forums is permitted, provided the original author(s) and the copyright owner(s) are credited and that the original publication in this journal is cited, in accordance with accepted academic practice. No use, distribution or reproduction is permitted which does not comply with these terms. 